Электронный научный журнал (Online). ISSN 2303-9922. http://www.vestospu.ru

УДК 377/378+[372.881.161.1+372.82]

DOI: 10.32516/2303-9922.2018.25.20

\title{
Н. В. Кудряшова
}

\section{Т. А. Острикова}

\section{Единые для школьников и студентов виды письменных работ по русскому языку и литературе: интонационный диктант фразово-предложенческий и текстовый (партитурный)}

В статье рассматривается интонационный (правописно-интонационный) диктант как единый для учащихся общей и профессиональной школы вид письменных работ по русскому языку и литературе. Раскрыто его значение и сущность, описаны фактические виды и технология выполнения. Правописно-интонационные диктанты подразделены на две группы — диктанты текстовые (они именованы партитурными) и нетекстовые, среди которых основными являются фразово-предложенческие. Актуализировано несколько технологических вопросов, в том числе: унификации и минимизации условно-графических обозначений компонентов интонации; интонационно-графической схематизации предложений; интонационной партитуры текста контрольного диктанта, т.е. его интонационно-графической разметки как основы выразительного чтения. Для подготовки к интонационным диктантам разработаны упражнения, направленные на формирование умения составлять интонационные схемы предложений и выполнять интонационно-графическую подготовку текста к выразительному чтению.

Ключевые слюва: виды письменных работ, интонационный диктант, выразительное чтение, интонационный принцип синтаксиса и пунктуации, русский язык и литература, учебный предмет в школе, вузовская дисциплина, интонационно-графические знаки и обозначения, интонационно-графическая схема предложения, интонационно-графическая разметка (партитура) текста.

Интонация - основное выразительное средство звучащей речи, выражающее конкретный смысл высказывания, его целевую установку и эмоционально-экспрессивные особенности [2, с. 96]. С точки зрения особенностей и техники устной речи интонация представляет собою единство взаимосвязанных компонентов - мелодики, силы, длительности, темпа произнесения, тембра и пауз, соотносимое с определённым набором языковых значений. В лингвистике интонация (интонология) изучается такими науками, как риторика, стилистика устной речи, фонетика; интонации уделяют внимание психолингвистика, психология, логопедия, физиология, физика, акустика и др.

Теория русской интонации описана в специальных лингвистических и лингвопрагматических исследованиях (Е. А. Брызгунова, Л. Л. Касаткин, И. Л. Муханов, Т. М. Николаева, Н. Д. Светозарова, Н. В. Черемисина и др.) $[2 ; 7 ; 15 ; 16 ; 23 ; 28]$. В средней общей школе и вузе необходимо изучать интонационный минимум, включающий 7 интонационных конструкций русского языка (по Е. А. Брызгуновой), хотя в чистом виде они не свойственны повседневной речи.

Методика обучения русской интонации представлена в достаточно широком круге работ по школьной методике и вузовской дидактике, особенно по теории и практике обучения русскому языку как государственному и иностранному (Т. М. Балыхина, И. М. Логинова, Л. Э. Лузикова, М. В. Маслова, Р. Д. Сафарян, Е. А. Сундарева и др.) [1; 9; 11; $14 ; 22 ; 25]$, в том числе в сопоставительном аспекте (А. А. Петрова, М. М. Рубер и др.) $[18 ; 19]$.

В рамках реализации метапредметного (межпредметного) подхода к обучению русскому языку и литературе в общей школе, а также метадидактического подхода к взаимосвязанному обучению школьников и студентов актуальна проблема непрерывного формирования речевого метаумения правильно интонировать устное высказывание на

(C) Кудряшова Н. В., Острикова Т. А., 2018 
Электронный научный журнал (Online). ISSN 2303-9922. http://www.vestospu.ru

русском языке - независимо от того, это чтение задания или стихотворения, устный ответ на учебную тему, устное сочинение или пересказ исходного текста, анализ синтаксической единицы или филологический анализ текста.

Опора на изучение интонации русского языка необходима при обучении его синтаксису и пунктуации, основанных не только на структурном и логико-смысловом принципах, но и на интонационном - подробнее см. в трудах А. М. Пешковского, С. И. Абакумова, А. Ф. Ломизова, А. В. Дудникова, Г. И. Блинова, Г. П. Фирсова и др. Зачастую интонация является «единственным смыслодифференцирующим признаком высказывания (особенно в условиях синтаксической омонимии)» [5, с. 108].

Правильная интонация - это составная часть культуры речи, «ибо человек, улавливающий ударения, паузы, мелодику тона, тембр голоса и темп речи с их смыслоразличительными функциями в процессе общения, может более гибко пользоваться ими, делая тем самым свою речь точной, выразительной и, следовательно, действенной» [10, с. 7]. Интонационное своеобразие устного ответа на лингвистическую или литературоведческую тему должно «соответствовать коммуникативно-речевой ситуации общения» [29, с. 54]. Невыразительная речь обедняет содержание высказывания ученика и учителя, затрудняет процесс аудирования диктантов и других текстовых работ, а «речь эмоционально окрашенная, интонационно разнообразная повышает интерес учеников, помогает восприятию и запоминанию сообщаемого материала» $[8$, с. 8]. Важно «совершенствовать речь будущих учителей-словесников ещё на вузовской скамье, ибо речь учителя должна быть примером для учеников, тем более что речь учащихся нередко развивается путём имитации, подражания речи взрослых, которую дети воспринимают в условиях как естественной, так и искусственной речевой среды» [12, с. 60].

Для будущих учителей русского языка и литературы важными являются метаумения: 1) выразительно читать художественный и иной текст, правильно и вариантно считывая его смысл, а также чувства и эмоции автора; 2) выполнять интонационно-графическую подготовку отдельных предложений и связных текстов к выразительному чтению. Умение выразительно читать текст необходимо при проведении диктантов и многих других работ, где присутствует диктовка текста, его пересказ, чтение вслух. Учитель-словесник должен уметь организовать наблюдения над интонационной стороной речи, правильно подобрать языковой материал для таких наблюдений, подготовить обучающихся к выразительному чтению текста, показать образец чтения, устного рассказа, прокомментировать само чтение.

Для формирования указанных выше метаумений следует более широко использовать интонационный диктант по русскому языку [17, с. 69-70]. Диктанту как типу письменных работ уделяется немало внимания во всех отраслях школьной методики преподавания русского языка и в русской лингводидактике в целом, в меньшей степени - в глоттодидактике на уровне частных методик преподавания иностранных языков.

В методике преподавания русского языка диктант рассматривается в основном как письменная работа, которая «строится на сравнении произношения с написанием» [26, c. 167] и учит переводить звучащую речь в письменную, т.е. заменять звуковой код буквенным, переводить орфоэпическую форму в графическо-каллиграфическую и орфографическую. Диктант как тип упражнений и текущих диагностических и итоговых контрольно-аттестационных работ основан на методе диктовки, поэтому является аудируемым письмом под диктовку.

Интонационный диктант мы рассматриваем не просто как вид работы по русскому языку, а более широко - как единый вид письменных работ по русскому языку и литературе. В школе и вузе данный вид диктанта необходим для изучения: а) правил интони- 
Электронный научный журнал (Online). ISSN 2303-9922. http://www.vestospu.ru

рования синтаксических единиц русского языка; б) словесного и логического ударения; в) правил пунктуации; г) теоретико-практических основ выразительного чтения прозаических и поэтических произведений. В вузе интонационный диктант рассматриваем также как специальный вид профессионально-методических работ, необходимых в системе подготовки будущих учителей-словесников, преподавателей русского языка как родного, государственного и иностранного (см. методику развития речи, обучения стилистике, грамматике и правописанию) и преподавателей литературы.

Такой метадидактический подход к описанию диктантов [17, с. 8$]$ предполагает опору на принципы: а) межпредметных связей учебных предметов в школе, который соответствует требованиям федеральных государственных образовательных стандартов, ориентированных на метапредметные результаты обучения; б) междисциплинарных и межнаучных связей в системе профессиональной подготовки в вузе.

С научно-методической точки зрения интонационный диктант, а точнее правописно-интонационный (партитурный) диктант [17, с. 68], относится к группе правописно-аспектных диктантов с дословной записью диктуемого материала. «Правописно-аспектный диктант - гибрид правописного и аспектного диктантов; правописный диктант с системно-языковой доминантой, с аспектными заданиями и разборами, включая грамматический» [17, с. 67]. Обучающий и проверочный правописно-интонационный диктант по преимуществу связан с проверкой знаний синтаксического и пунктуационно-синтаксического материала и умений отражать интонационный рисунок синтагм и предложений, реже - текстов и текстовых фрагментов.

С технологической точки зрения интонационный диктант проводится в два этапа: сначала пишется как классический правописный диктант (обязательно на контекстном дидактическом материале), который может быть словосочетательным, фразово-предложенческим и текстовым. Затем на основе записанных языковых/речевых примеров школьники и студенты выполняют интонационно-графический разбор.

В школе в основном практикуется разбор частичный: в словосочетаниях, типовых фразах или авторских предложениях ученики ставят отдельные (изученные!) интонационно-графические знаки между словами, а также над и под ними. На филологических факультетах вузов и в театральных институтах уместен полный интонационно-графический разбор в виде партитурной разметки связного текста. Такой диктант необходим в основном на уроках литературы с целью изучения особенностей выразительного чтения прозаических и поэтических произведений разных жанров (напр.: [4, с. 65; 6]).

Партитурный диктант особо актуален в рамках учебного курса методики русского языка, так как помогает студентам подготовиться к чтению текстового контрольного диктанта. Хотя филологи изучают основы выразительного чтения, их практическая подготовка недостаточна, и она, к сожалению, мало совершенствуется в курсах русской и зарубежной литературы.

Навыки выразительного чтения явно недостаточны и у школьников, особенно билингвов и инофонов, в родных языках которых интонация может отличаться от русской интонации, в связи с чем имеет место «импортирование» в русский язык интонационных параметров родного языка [18]. «Если для носителя русского языка ценностно-интонационный контекст художественного целого понятен, ощутим, проговаривается во внутренней речи, то иноязычным учащимся непросто его почувствовать и понять. <..> В большинстве своём ценностно-интонационный контекст чужой культуры сложно понять именно потому, что он “чужой”, то есть окутан сетью интонационно-ментальных наслоений, чаще всего национально специфически окрашенных» [22, с. 46]. Например, 
Электронный научный журнал (Online). ISSN 2303-9922. http://www.vestospu.ru

иностранцы иногда воспринимают русскую повествовательную интонацию, отличающуюся понижением голоса в конце предложения, как резкую и даже «агрессивную».

В вузе с лингводидактической точки зрения важно, какие конструкции подвергаются анализу - языковые или речевые. К первым принято относить типовые синтаксические единицы с упрощённым языковым наполнением - см. типичные словосочетания (синтагмы), типовые фразы-предложения и стандартные тексты. Ко вторым относят аутентичные и поэтому вариантно интерпретируемые высказывания - авторские предложения и неадаптированные связные тексты, имеющие вариантное интонационное оформление.

Для общеобразовательной школы правописно-интонационный диктант мы подразделяем на две группы по характеру языкового материала. По этому параметру диктант может быть, во-первых, нетекстовым - (1) словосочетательным, или синтагматическим, и (2) фразово-предложенческим; они включают дополнительное задание произвести интонационно-графический разбор сложных словосочетаний и отдельных относительно коротких предложений; во-вторых, текстовым - с интонационно-графическим разбором относительно коротких связных текстов. В результате можно говорить о трёх видах интонационных диктантов с дополнительным заданием произвести интонационно-графический разбор записанного материала.

1. Синтагматический интонационный диктант «Интонация синтагмы». Задание. Записать диктант без изменений; затем произвести интонационный разбор, т.е. графически обозначить интонационный рисунок словосочетаний - например с однородными и обособленными определениями.

2. Фразово-предложенческий интонационный диктант «Интонация простого/ сложного предложения». Задание. Записать диктант без изменений; затем произвести интонационный разбор записанных типовых и/или аутентичных предложений: графически обозначить интонационный рисунок предложений; записать отдельно интонационные схемы всех или некоторых предложений.

3. Партитурный диктант «Выразительное чтение текста» - это правописно-интонационный диктант с условно-графическим обозначением особенностей выразительного чтения художественного текста. Необходим как средство письменной подготовки к выразительному чтению конкретных поэтических и прозаических произведений учебного курса литературы. Задание. Запишите текст дословно через строчку, чтобы создать пространство для условно-графической разметки (она обычно делается простым карандашом). Каждое предложение читается выразительно - сначала учителем, потом учениками.

Интонационный диктант оценивается двумя отметками: первая ставится за правописание (орфография + пунктуация), а вторая - за интонационный разбор, здесь бывает достаточно по системе зачтено - не зачтено. В обучающих диктантах отметку за правильность интонационного рисунка рекомендуем ставить выборочно, даже если визуальные опоры с образцами интонирования были открыты.

Рассмотрим подробнее вопросы, связанные с интонационно-графической разметкой предложений и текстов. Школьники и студенты много лет изучают русский язык и литературу, но читать выразительно умеют не все, что во многом связано с недостаточным вниманием педагогов к технической стороне выразительного чтения, а именно к интонационно-графической разметке текста. Она сопровождается выразительным чтением вслух — индивидуально и хором. Выполняется по изученным образцам с помощью специальных условных обозначений. В их числе восходящие и нисходящие стрелочки, символизирующие повышение и понижение тона/голоса; вертикальные чёрточки (одинарные, двойные, тройные) для обозначения пауз разной длины; подчёркивание слов с 
Электронный научный журнал (Online). ISSN 2303-9922. http://www.vestospu.ru

логическим ударением; графические скрепы, показывающие отсутствие пауз между словами и др.

Приведём типичную инструкцию к фразовому интонационному диктанту, данную в упражнении 87 учебника для 8 класса. «При записи отмечайте одной вертикальной линией небольшую паузу между группой подлежащего, т.е. подлежащего с зависимыми словами, и группой сказуемого, т.е. сказуемого с зависимыми словами. Двумя вертикальными линиями обозначьте интонацию законченности в конце повествовательного предложения. Обозначьте повышение голоса перед паузой в середине предложения и понижение на последнем ударном слоге последнего слова в предложении» [20, с. 44].

Чтобы качественно выполнить любой из видов интонационного диктанта, необходимо познакомить обучаемых со специальными условными графическими обозначениями компонентов интонации. Образцы интонационной графической разметки предложений разного строения присутствуют в учебных пособиях, параллельных школьных учебниках по русскому языку, а варианты интонирования текстов разных жанров - в изданиях по выразительному чтению и сценической речи.

Схематизация производится после записи каждого отдельного предложения. Интонационная схема предложения обусловлена пунктуационно-синтаксической, но не совпадает с ней. Подготовка к диктанту предполагает работу по правильному интонированию, чтобы ученики услышали от учителя нужную интонацию, отражающую смысловые отношения и, соответственно, постановку знаков препинания.

Интонационная разметка текста важна прежде всего для учителя, так как «если учитель вооружен стабильными интонационными навыками, каждый диктант в его исполнении становится <..> не только средством проверки грамотности учащихся, но и средством и способом (для учащихся!) своего рода подтверждения тех интонационных образцов, которые они под руководством учителя усвоили» [3, с. 27].

В школьных учебниках имеются упражнения, которые можно квалифицировать как интонационные диктанты, где представлены образцы интонационно-графических обозначений на примере отдельных простых и сложных предложений. Так, над словом, на которое падает логическое ударение, предлагается ставить знак секунды "; восходящую и нисходящую интонации, т.е. повышение и понижение тона/голоса, принято обозначать соответствующими стрелочками, а межсинтагматические паузы - наклонными вертикальными чёрточками: / - короткая; // - длительная [21, с. 32]. В таком случае интонационный рисунок предложения выглядит следующим образом:

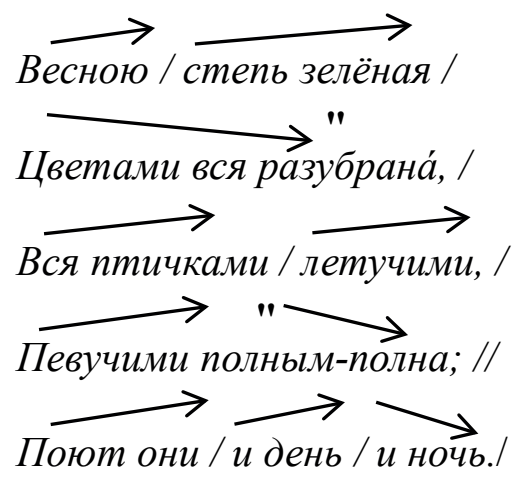

(А. Кольцов)

Учёный-методист С. И. Львова рекомендует показывать особенности логического ударения в типичных синтаксических конструкциях: 1) выделять логическим ударением противопоставляемые понятия: первый член пары (отрицаемое) выделяется повыше- 
Электронный научный журнал (Online). ISSN 2303-9922. http://www.vestospu.ru

нием голоса, второй (утверждаемое) - понижением; 2) ставить логическое ударение в конструкциях сравнения; 3) выделять логическим ударением новое понятие [13, с. 163].

Реализацию первого требования представим на примере, в котором двумя чертами подчёркнуто слово с сильным логическим ударением, одной чертой - со слабым логическим ударением, а стрелками обозначен пик повышения или понижения голоса при логическом ударении.

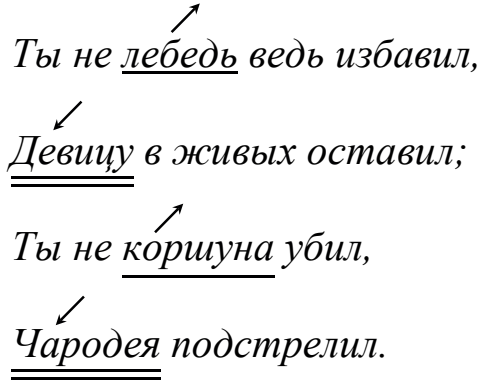

(А. С. Пушкин)

При партитурной разметке связного текста добавляются удлинённые межфразовые паузы (на 3 счёта - ///) между предложениями и абзацами, а также повышение и понижение тона при чтении отдельных предложений и абзацев. Необходимо акцентировать внимание обучающихся на значении отдельных компонентов интонации. Так, например, паузы не только помогают воспринимать на слух речевое высказывание, но и способствуют его пониманию, смысловой дешифровке. Сокращение пауз, ускоренная речь (скороговоркой) затрудняют процесс аудирования, поэтому соблюдение пауз принципиально важно при обучении устной речи учащихся, особенно инофонов.

Такой компонент интонации, как темп речи, обычно связывают с эмоциональным настроем говорящего, его речевой индивидуальностью. Но при этом учащимся необходимо объяснить, что темп речи намеренно меняется, т.е. регулируется: 1) в зависимости от стилевой принадлежности текста высказывания (высказывание, реализующее текст научного или официально-делового стилей, произносится медленнее, чем высказывание, реализующее текст художественного, публицистического или разговорного стилей); 2) медленнее произносится и новая, важная или предъявляемая впервые информация, быстрее - известная, второстепенная.

Особую функцию выполняет тембр речи - окрашенность, которая образуется путём использования дополнительных к основному тонов - обертонов. Тембр позволяет передать эмоциональную основу произведения и наше к нему отношение. «Если наши ученики овладеют логической выразительностью чтения, но не будут пользоваться тембральным окрашиванием речи, их чтение окажется правильным, понятным, но бездушным, неэмоциональным» [24, с. 69]. Следовательно, тембр - такой компонент интонации, которому также необходимо уделять внимание. «В рамках отдельного предложения при помощи тембрального окрашивания мы передадим удивление, радость, негодование, присоединение к чужому высказыванию, иронию и т.п. В рамках целого произведения или законченного отрывка определённый тембр поможет чтецу сообщить исполняемому характер грустного повествования, философского раздумья, юмористического рассказа, простой правды, дружеской шутки, негодующей сатиры и т.п.» [там же].

Как показывает практика, трудности вызывает определение изменений высоты голоса. Для тренировки данного умения можно использовать «дирижирование» - интонационно-слуховые диктанты, «заключающиеся в том, что учитель читает предложение, а учащиеся в это время движением рук показывают, повышается или понижается на том 
Электронный научный журнал (Online). ISSN 2303-9922. http://www.vestospu.ru

или ином слове голос. Ошибки, которые допускают школьники, учитель замечает и просит другого ученика повторить упражнения» [27, с. 186].

Большое внимание лингвисты и методисты уделяют условно-графическим знакам и обозначениям, необходимым для адекватного отражения интонационно-смысловой структуры предложения и особенностей выразительного чтения текстов.

Визуально-графическая схема словосочетаний, предложений, целого текста является своеобразной зрительной опорой для их адекватного восприятия и понимания. Интонационно-графические схемы представлены в разнообразных лингводидактических источниках, в том числе это школьные и вузовские учебники и учебные пособия, журнальные статьи, пособия по выразительному чтению и сценической речи. Их анализ показал, что полного единства в интонационно-графическом разборе, конечно, нет, но есть общие группы условных знаков и обозначений. Например, повышение и понижение голоса принято обозначать стрелками, но они визуально разнообразны, так как могут быть прямые и с изгибом, непрерывные и пунктирные, короткие и длинные и др.

Следовательно, перед потенциальным и реальным учителем и преподавателем русского языка и литературы стоит проблема отбора минимума условных графических обозначений. Полагаем, что для решения обозначенной проблемы в учебных целях необходимо упрощение условных обозначений, их унификация для школы и вуза, для учителя и преподавателя, ученика и студента. Из всего разнообразия вариантов графического обозначения компонентов интонации для интонационного диктанта в школе и вузе необходимо составить учебный минимум условных знаков и графических обозначений (табл. 1).

Таблица 1

Учебный минимум интонационно-графических условных знаков и обозначений

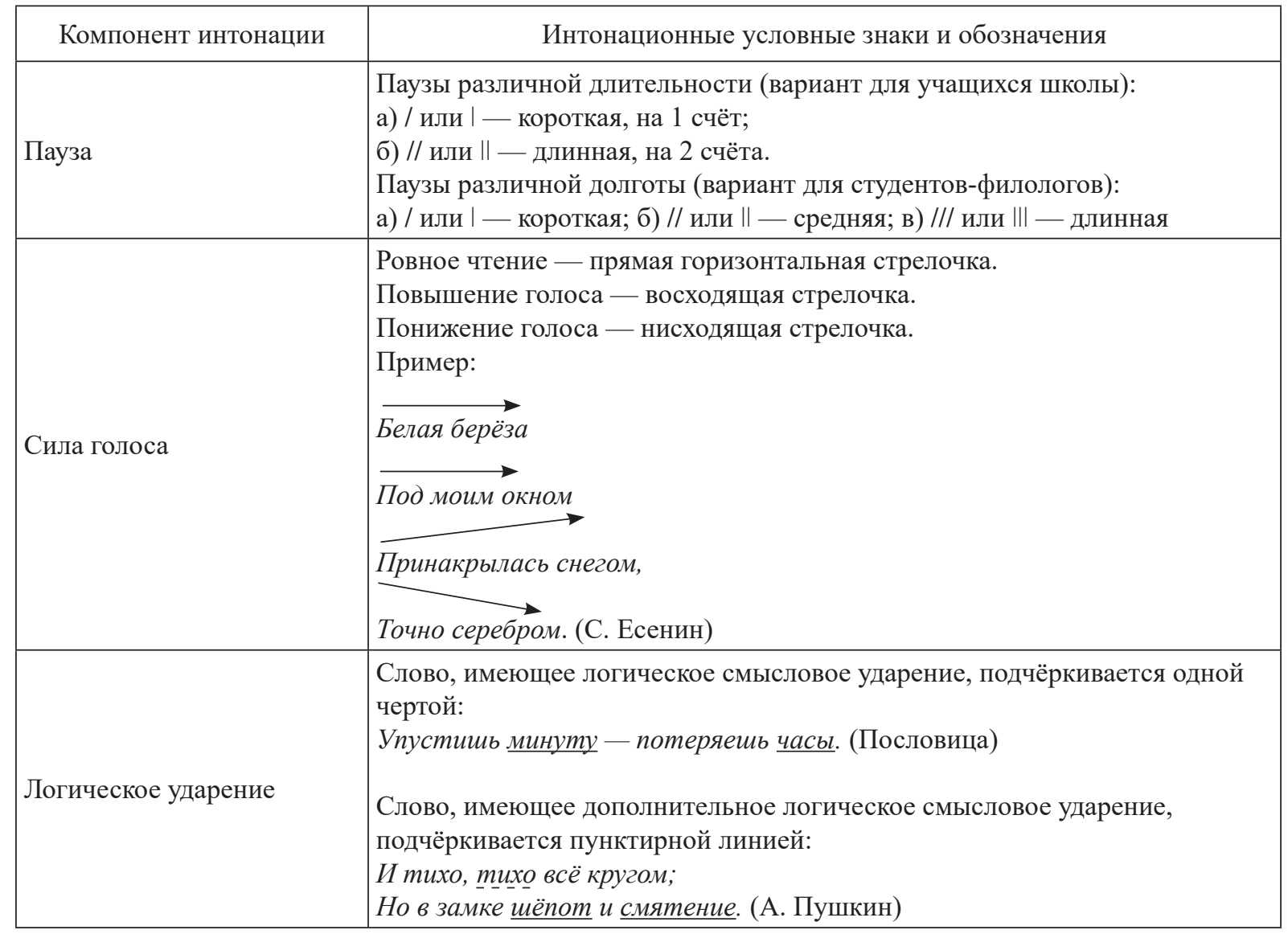


Электронный научный журнал (Online). ISSN 2303-9922. http://www.vestospu.ru

Продолжение табл. 1

\begin{tabular}{|c|c|}
\hline Компонент интонации & Интонационные условные знаки и обозначения \\
\hline Синтагматическое ударение & $\begin{array}{l}\text { Слово, имеющее синтагматическое ударение, подчёркивается волнистой } \\
\text { чертой: } \\
\text { Молчат гробнииь, мумии и кости, - } \\
\text { Лишь слову жизнь дана: } \\
\text { Из древней тьмы, на мировом погосте } \\
\text { 3вучат лишь Письмена. (И. Бунин) }\end{array}$ \\
\hline Темп чтения & $\begin{array}{l}\text { Можно обозначить соответствующей буквой: } \\
\text { a) нормальный - н. } \\
\text { б) медленный - м. } \\
\text { в) быстрый - б. }\end{array}$ \\
\hline
\end{tabular}

При выполнении обучающих интонационно-графических заданий и проверочных работ представленный на примерах упрощённый комплект условных знаков и обозначений полезно использовать в виде индивидуальной памятки и настенного или экранного плаката. Это помогает добиться унифицированной графической разметки предложений и связных текстов и тем самым облегчает проверку и самопроверку, оценку и взаимооценку работ. Представим образец интонационной партитуры прозаического текста.

И. С. Тургенев. Русский язык (стихотворение в прозе)

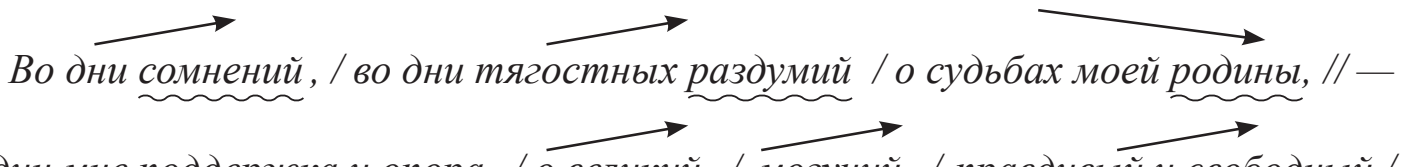
тыл один мне поддержка и опора , / $\overleftrightarrow{\text { великий }, ~ / ~}$ русский язык! /// — Не будь тебя — / как не впасть в отчаяние / при виде всего, / что

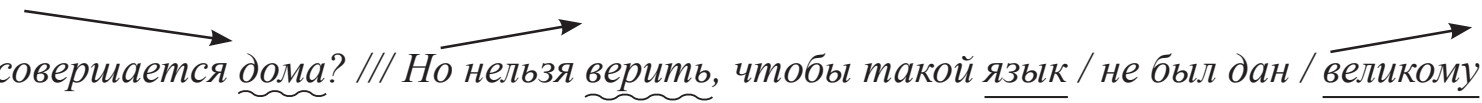
народy!

Обучающий правописно-интонационный диктант вначале выполняется как упражнение, но постепенно становится контрольно-обучающим. Это позволяет непрерывно развивать, а попутно диагностировать интонационные умения, без которых затруднительно усвоить синтаксис и пунктуацию.

Рассмотрим варианты заданий для подготовки к интонационным диктантам разных видов - на уровне синтагмы, предложения и текста. Интонационные упражнения и задания, как и соответствующие диктанты (см. выше), мы подразделяем на 3 группы:

1) интонационно-синтагматические;

2) интонационно-фразовые/интонационно-предложенческие;

3) интонационно-текстовые.

Первая и вторая группа упражнений и заданий являются общими для школьников и студентов, изучающих русский язык. Третья группа актуальна для уроков литературы в школе, а также необходима для студентов-филологов, овладевающих навыками выразительного чтения текстов, в том числе предназначенных для изложений и диктантов.

Приведём образцы заданий с минимумом языковых примеров.

Задание 1. Разделите данные предложения на синтагмы, расставьте паузы. В каждой синтагме выделите слова с логическим ударением, отметьте повышение и понижение 
Электронный научный журнал (Online). ISSN 2303-9922. http://www.vestospu.ru

тона голоса. Подумайте, чем обусловлено синтагматическое членение в данных предложениях. Произнесите предложения вслух в соответствии с графической разметкой.

1. Узорчатые края облаков, пушистые и лёгкие, изменялись с каждым мгновением. (И. Тургенев)

2. Замевелились, тревожно зашумели, застонали, заскрипели над головой сосныл. (Б. Полевой)

Задание 2. Составьте интонационные схемы предложений: расставьте паузы, стрелочками отметьте повышение и понижение тона голоса. Произнесите предложения вслух в соответствии с графической разметкой.

1. Завтра наш класс идёт на выставку современного искусства.

2. Завтра наш класс идёт на выставку современного искусства?

3. Мы идём на выставку!

\section{Задание 3}

3.1. Вариант для школьников. Подготовьте текст для выразительного чтения: выявите количество и границы синтагм в каждом предложении; слова, на которые падают синтагматические и фразовые ударения; повышение и понижение тона голоса. Прочитайте текст вслух в соответствии с графической разметкой.

3.2. Вариант для студентов. Подготовьте партитуру для выразительного чтения текста диктанта в классе на уроке: выявите количество и границы синтагм в каждом предложении; слова, на которые падают синтагматические и фразовые ударения; повышение и понижение тона голоса. Прочитайте текст вслух в соответствии с графической разметкой (партитурой).

\section{Уmёc}

Ночевала тучка золотая

На груди утёса-великана;

Утром в путь она умчалась рано,

По лазури весело играя;

Но остался влажный след в морщиине

Старого утёса. Одиноко

Он стоит, задумался глубоко

И тихонько плачет он в пустыне.

(М. Ю. Лермонтов)

Итак, при обучении русскому языку и литературе русскоязычных школьников и студентов, а также билингвов и инофонов необходимо использовать разнообразные виды интонационных диктантов. Умение обучаемых и обучающих правильно интонировать словосочетания, предложения и тексты позволит эффективнее усваивать синтаксис и пунктуацию, развивать навыки выразительного чтения текстов, помогающие правильно понимать и передавать смысл высказывания, его ценностно-эмоциональную составляющую.

\section{Список использованной литературы}

1. Балыхина Т. М. Методика преподавания русского языка как неродного (нового) : учеб. пособие для преподавателей и студентов. М. : Изд-во Рос. ун-та дружбы народов, 2007. 185 с.

2. Брызгунова Е. А. Интонация // Русская грамматика : в 2 т. М. : Наука, 1980. Т. 1. Фонетика. Фонология. Ударение. Интонация. Словообразование. Морфология. С. 96-120. 


\section{Электронный научный журнал (Online). ISSN 2303-9922. http://www.vestospu.ru}

3. Бухарин В. И. Пунктуационный разбор и работа над интонацией // Русский язык в школе. 1972. № 3. C. $21-28$.

4. Ваганова А. К. Интонационно-стилистическая работа по изучению знаков препинания на уроках словесности // Обучение русскому языку в средней школе: актуальные вопросы теории и практики : материалы I Всерос. науч.-практ. конф. / отв. ред. В. Ю. Меликян. Ростов-на-Дону : Дониздат, 2015. С. 65-72.

5. Власов М. С. Просодические основы процесса расстановки знаков препинания в текстах с синтаксической омонимией (на материале обособленных членов) // Филология и человек. Барнаул : АлтГУ, 2007. № 3. С. $108-114$.

6. Выразительное чтение : учеб. пособие для педвузов / С. Т. Никольская, А. В. Майорова, В. В. Осокин ; ред. Н. М. Шанский. Л. : Просвещение : Ленингр. отд-ние, 1990. 205 с.

7. Касаткин Л. Л. Русская интонация: тональные контуры // Проблемы фонетики : сб. статей / отв. ред. Р. Ф. Касаткина ; Ин-т рус. яз. им. В. В. Виноградова РАН. М. : Наука, 2007. Вып. 5. С. 250-266.

8. Князьков А. А. Техника речи и постановка голоса : метод. разработки. Вып. 1. М. : МГПИ им. В. И. Ленина, 1985. 54 с.

9. Логинова И. М. О «вопросительной» и «восклицательной» интонации в научной и школьной грамматике // Лингвистика и школа-IV. К 90-летию со дня рождения Михаила Викторовича Панова (1920$2001)$ : материалы Всерос. науч.-практ. конф. (1-3 нояб. 2010 г.) / под ред. Л. Б. Парубченко. Барнаул : Изд-во Алт. ун-та, 2011. С. 110-117.

10. Ломизов А. Ф. Выразительное чтение при изучении синтаксиса и пунктуации : пособие для учит. 2-е изд., перераб. М. : Просвещение, 1986. 96 с.

11. Лузикова Л. Э. Обучение иностранных учащихся интонации как средству реализации речевой интенции (на примере порогового уровня владения русским языком) // Русский язык за рубежом. 2010 . № 6. C. $53-58$.

12. Лыжова Л. К. Совершенствование устной речи будущих учителей русского языка // Обучение устной речи учащихся в школе на уроках русского языка и студентов филфаков вузов : тез. докл. межвуз. науч.-практ. конф. / сост. М. Т. Баранов. М. : МПГУ им. В. И. Ленина, 1995. С. 60-61.

13. Львова С. И. Уроки словесности. 5-9 классы. 2-е изд. М. : Дрофа, 1997. 416 с.

14. Маслова М. В. Изучение интонации вопросительных предложений с опорой на аудирование в VVI классах основной школы // Русский язык в школе. 2018. № 1. С. 3-8.

15. Муханов И. Л., Кумико Сагава. Прагматические аспекты русской интонации (на материале вторичных употреблений интонационных конструкций) // Русский язык за рубежом. 2013. № 2. С. 57 -63.

16. Николаева Т. М. ИК у Е. А. Брызгуновой и проблемы интонационной типологии // Вопросы русского языкознания. М. : Изд-во Моск. ун-та, 2004. Вып. ХІ : Аспекты изучения звучащей речи. С. $154-162$.

17. Острикова Т. А. Методика изучения орфографии, пунктуации и иных разделов русского языка. История, теория и практика диктанта : учеб. пособие. Абакан : Хакасский гос. ун-т им. Н. Ф. Катанова, 2016. $176 \mathrm{c}$.

18. Петрова А. А. Просодия речи при раннем билингвизме // Русский язык за рубежом. 2009. № 6. C. $88-94$.

19. Рубер М. М. Интонационные конструкции в русском и французском языках // Русский язык за рубежом. 1989. № 4. С. $78-82$.

20. Русский язык: 8 класс : учеб. / Л. А. Тростенцова, Т. А. Ладыженская, А. Д. Дейкина, О. М. Александрова. М. : Просвещение, 2010. 237 с.

21. Русский язык : 8 класс : учеб. / М. М. Разумовская, С. И. Львова, В. И. Капинос, В. В. Львов ; под ред. М. М. Разумовской, П. А. Леканта. М. : Дрофа, 2009. 269 с.

22. Сафарян Р. Д. Интонационная вселенная русского дискурса: лингводидактический аспект // Русский язык за рубежом. 2011. № 5. С. 43-47.

23. Светозарова Н. Д. Интонационная система русского языка. Л. : Изд-во Ленингр. ун-та, 1982. 176 с.

24. Стракевич М. М. Работа над выразительным чтением при изучении русского языка. V-VIII классы / ред. А. В. Текучёв. М. : Просвещение, 1964. 119 с.

25. Сундарева Е. А. Работа над интонацией при изучении пунктуационных знаков завершения // Обучение устной речи учащихся в школе на уроках русского языка и студентов филфаков вузов : тез. докл. межвуз. науч.-практ. конф. / сост. М. Т. Баранов. М. : МПГУ им. В. И. Ленина, 1995. С. 39 — 41.

26. Федоренко Л. П. Принципы и методы обучения русскому языку : пособие для студ. пед. ин-тов. М. : Просвещение, 1964. 255 с.

27. Фирсов Г. П. Значение работы над интонацией для усвоения синтаксиса и пунктуации в школе / ред. В. В. Виноградов. М. : АПН РСФСР, 1962. 448 с.

28. Черемисина Н. В. Русская интонация: поэзия, проза, разговорная речь. М. : Русский язык, 1989. $240 \mathrm{c}$. 
Электронный научный журнал (Online). ISSN 2303-9922. http://www.vestospu.ru

29. Черепанова Л. В., Трофимова О. В. Обучение аудированию на уроках русского языка : учеб.-метод. пособие / ред. Л. В. Черепанова. Чита : ЗабГГПУ им. Н. Г. Чернышевского, 2012. 218 с.

Поступила в редакцию 16.01.2018

\begin{abstract}
Кудряшова Наталия Владимировна, кандидат педагогических наук
Хакасский государственный университет им. Н. Ф. Катанова

Российская Федерация, 655017, Республика Хакасия, г. Абакан, ул. Ленина, 90

E-mail: nataliya-15.72@mail.ru
\end{abstract}

Острикова Татьяна Александровна, доктор педагогических наук, доцент

Хакасский государственный университет им. Н. Ф. Катанова

Российская Федерация, 655017, Республика Хакасия, г. Абакан, ул. Ленина, 90

E-mail: t.a.ostrikova@mail.ru

UDC 377/378+[372.881.161.1+372.82]

\title{
N. V. Kudryashova
}

\section{T. A. Ostrikova}

\section{Unified types of written works in Russian language and literature for school and university students: phrase and textual intonational dictation}

The article regards the intonational dictation as a unified type of written works in Russian and Literature for school and university students. It reveals its importance and meaning; describes its types and technology. Intonational dictations are divided into two groups: text dictations and non-text dictations among which phrase and sentence dictations are the basic types. The following technological issues have been foregrounded: unification and minimization of symbols of intonation components; intonational and graphical sentence patterning; stress and intonation marking of the text for dictation test. The article introduces dictation exercises intended to develop the skills to make up intonation patterns of sentences and carry out intonational and graphical preparation of the text for dramatic reading.

Key words: types of written works, intonational dictation, dramatic reading, intonational principle of syntax and punctuation, the Russian language and Literature, school subject, university discipline, intonational and graphical symbols, intonational and graphical sentence patterns, intonational and graphical text marking.

Kudryashova Nataliya Vladimirovna, Candidate of Pedagogical Sciences

Katanov Khakass State University

Russian Federation, 655017, Republic of Khakassia, Abakan, ul. Lenina, 90

E-mail: nataliya-15.72@mail.ru

Ostrikova Tatyana Aleksandrovna, Doctor of Pedagogical Sciences, Assistant Professor

Katanov Khakass State University

Russian Federation, 655017, Republic of Khakassia, Abakan, ul. Lenina, 90

E-mail: t.a.ostrikova@mail.ru

\section{References}

1. Balykhina T. M. Metodika prepodavaniya russkogo yazyka kak nerodnogo (novogo) [Teaching Russian as a second (new) language]. Moscow, Ros. un-t druzhby narodov Publ., 2007. 185 p. (In Russian)

2. Bryzgunova E. A. Intonatsiya [Intonation]. Russkaya grammatika: $v 2 t$. [Russian grammar: in 2 volumes]. Moscow, Nauka Publ., 1980, vol. 1, pp. 96-120. (In Russian)

3. Bukharin V. I. Punktuatsionnyi razbor i rabota nad intonatsiei [Punctuation analysis and work on intonation]. Russkii yazyk v shkole, 1972, no. 3, pp. 21-28. (In Russian) 


\section{Электронный научный журнал (Online). ISSN 2303-9922. http://www.vestospu.ru}

4. Vaganova A. K. Intonatsionno-stilisticheskaya rabota po izucheniyu znakov prepinaniya na urokakh slovesnosti [Intonational and stylistic work on the study of punctuation marks at the lessons of literature]. Obuchenie russkomu yazyku v srednei shkole: aktual'nye voprosy teorii i praktiki: materialy I Vseros. nauch.prakt. konf. [Russian language teaching in secondary school: pressing issues of theory and practice. Materials of the I All-Russia scientific-practical conf.]. Rostov-na-Donu, Donizdat Publ., 2015, pp. 65-72. (In Russian)

5. Vlasov M. S. Prosodicheskie osnovy protsessa rasstanovki znakov prepinaniya v tekstakh s sintaksicheskoi omonimiei (na materiale obosoblennykh chlenov) [Prosodic foundations of the process of placing punctuation marks in texts with syntactic homonymy (on the material of isolated members)]. Filologiya $i$ chelovek [Philology and Man]. Barnaul, AltGU Publ., 2007, no. 3, pp. 108-114. (In Russian)

6. Nikol'skaya S. T., Maiorova A. V., Osokin V. V. Vyrazitel'noe chtenie [Expressive reading]. Leningrad, Prosveshchenie, Leningr. otd-nie Publ., 1990. 205 p. (In Russian)

7. Kasatkin L. L. Russkaya intonatsiya: tonal'nye kontury [Russian intonation: tonal contours]. Problemy fonetiki: sb. statei [Problems of phonetics: coll. articles]. Moscow, Nauka Publ., 2007, is. 5, pp. 250_266. (In Russian)

8. Knyaz'kov A. A. Tekhnika rechi i postanovka golosa: metod. razrabotki [Speech technique and voice setting: method. development]. Is. 1. Moscow, MGPI im. V. I. Lenina Publ., 1985. 54 p. (In Russian)

9. Loginova I. M. O “voprositel'noi” i “vosklitsatel'noi” intonatsii v nauchnoi i shkol'noi grammatike [About "interrogative" and "exclamatory" intonation in scientific and school grammar]. Lingvistika i shkola-IV. K 90-letiyu so dnya rozhdeniya Mikhaila Viktorovicha Panova (1920-2001): materialy Vseros. nauch.-prakt. konf. (1-3 noyab. 2010 g.) [Linguistics and School-IV. To the $90^{\text {th }}$ anniversary of Mikhail Viktorovich Panov (1920 - 2001): materials of All-Russia scientific-practical conf. (1-3 November 2010)]. Barnaul, Alt. un-t Publ., 2011, pp. 110 - 117. (In Russian)

10. Lomizov A. F. Vyrazitel'noe chtenie pri izuchenii sintaksisa i punktuatsii [Expressive reading in the study of syntax and punctuation]. Moscow, Prosveshchenie Publ., 1986. 96 p. (In Russian)

11. Luzikova L. E. Obuchenie inostrannykh uchashchikhsya intonatsii kak sredstvu realizatsii rechevoi intentsii (na primere porogovogo urovnya vladeniya russkim yazykom) [The training of foreign students in intonation as a means of implementing a verbal intent (on the example of the threshold level of knowledge of the Russian language)]. Russkii yazyk za rubezhom, 2010, no. 6, pp. 53-58. (In Russian)

12. Lyzhova L. K. Sovershenstvovanie ustnoi rechi budushchikh uchitelei russkogo yazyka [Perfection of oral speech of the future teachers of the Russian language]. Obuchenie ustnoi rechi uchashchikhsya v shkole na urokakh russkogo yazyka i studentov filfakov vuzov: tez. dokl. mezhvuz. nauch.-prakt. konf. [Training of oral speech of schoolchildren at the lessons of the Russian language and students of philological faculties of high schools: theses of interuniversity scientific-practical conf.]. Moscow, MPGU im. V. I. Lenina Publ., 1995, pp. 60-61. (In Russian)

13. L'vova S. I. Uroki slovesnosti. 5-9 klassy [Lessons of literature. Grades 5-9]. Moscow, Drofa Publ., 1997. 416 p. (In Russian)

14. Maslova M. V. Izuchenie intonatsii voprositel'nykh predlozhenii s oporoi na audirovanie v V-VI klassakh osnovnoi shkoly [Studying the intonation of interrogative sentences based on listening in V-VI classes of the main school]. Russkii yazyk v shkole, 2018, no. 1, pp. 3-8. (In Russian)

15. Mukhanov I. L., Kumiko Sagava. Pragmaticheskie aspekty russkoi intonatsii (na materiale vtorichnykh upotreblenii intonatsionnykh konstruktsii) [Pragmatic aspects of Russian intonation (based on secondary usage of intonational constructions)]. Russkii yazyk za rubezhom, 2013, no. 2, pp. 57-63. (In Russian)

16. Nikolaeva T. M. IK u E. A. Bryzgunovoi i problemy intonatsionnoi tipologii [Intonation construction by E. A. Bryzgunova and problems of intonational typology]. Voprosy russkogo yazykoznaniya [Questions of Russian Linguistics]. Moscow, Izd-vo Mosk. un-ta Publ., 2004, is. 11, pp. 154-162. (In Russian)

17. Ostrikova T. A. Metodika izucheniya orfografii, punktuatsii i inykh razdelov russkogo yazyka. Istoriya, teoriya i praktika diktanta [The method of studying spelling, punctuation and other sections of the Russian language. History, theory and practice of dictation]. Abakan, Khakasskii gos. un-t im. N. F. Katanova Publ., 2016. 176 p. (In Russian)

18. Petrova A. A. Prosodiya rechi pri rannem bilingvizme [Prosody of speech in early bilingualism]. Russkii yazyk za rubezhom, 2009, no. 6, pp. 88-94. (In Russian)

19. Ruber M. M. Intonatsionnye konstruktsii v russkom i frantsuzskom yazykakh [Intonation constructions in Russian and French]. Russkii yazyk za rubezhom, 1989, no. 4, pp. 78-82. (In Russian)

20. Trostentsova L. A., Ladyzhenskaya T. A., Deikina A. D., Aleksandrova O. M. Russkii yazyk: 8 klass [Russian language: Class 8]. Moscow, Prosveshchenie Publ., 2010. 237 p. (In Russian)

21. Razumovskaya M. M., L'vova S. I., Kapinos V. I., L’vov V. V. Russkii yazyk: 8 klass [Russian language: Class 8]. Moscow, Drofa Publ., 2009. 269 p. (In Russian) 


\section{Электронный научный журнал (Online). ISSN 2303-9922. http://www.vestospu.ru}

22. Safaryan R. D. Intonatsionnaya vselennaya russkogo diskursa: lingvodidakticheskii aspekt [The intonational universe of Russian discourse: the linguodidactic aspect]. Russkii yazyk za rubezhom, 2011, no. 5, pp. 43 - 47. (In Russian)

23. Svetozarova N. D. Intonatsionnaya sistema russkogo yazyka [Intonation system of the Russian language]. Leningrad, Leningr. un-t Publ., 1982. 176 p. (In Russian)

24. Strakevich M. M. Rabota nad vyrazitel'nym chteniem pri izuchenii russkogo yazyka. V-VIII klassy [Work on expressive reading in the study of the Russian language. V-VIII classes]. Moscow, Prosveshchenie Publ., 1964. 119 p. (In Russian)

25. Sundareva E. A. Rabota nad intonatsiei pri izuchenii punktuatsionnykh znakov zaversheniya [Work on intonation in the study of punctuation marks of completion]. Obuchenie ustnoi rechi uchashchikhsya $v$ shkole na urokakh russkogo yazyka i studentov filfakov vuzov: tez. dokl. mezhvuz. nauch.-prakt. konf. [Speech training of schoolchildren at the lessons of the Russian language and students of philology at the universities: theses of interuniversity scientific-practical conf.] Moscow, MPGU im. V. I. Lenina Publ., 1995, pp. 39 — 41. (In Russian)

26. Fedorenko L. P. Printsipy i metody obucheniya russkomu yazyku [Principles and methods of teaching the Russian language]. Moscow, Prosveshchenie Publ., 1964. 255 p. (In Russian)

27. Firsov G. P. Znachenie raboty nad intonatsiei dlya usvoeniya sintaksisa i punktuatsii v shkole [The importance of working on intonation for mastering syntax and punctuation in school]. Moscow, APN RSFSR Publ., 1962. 448 p. (In Russian)

28. Cheremisina N. V. Russkaya intonatsiya: poeziya, proza, razgovornaya rech' [Russian intonation: poetry, prose, colloquial speech]. Moscow, Russkii yazyk Publ., 1989. 240 p. (In Russian)

29. Cherepanova L. V., Trofimova O. V. Obuchenie audirovaniyu na urokakh russkogo yazyka [Learning to listen at the Russian language lessons]. Chita, ZabGGPU im. N. G. Chernyshevskogo Publ., 2012. 218 p. (In Russian) 